The Playful Citizen 



\title{
The Playful Citizen
}

Civic Engagement in a Mediatized Culture

\author{
Edited by
}

René Glas, Sybille Lammes, Michiel de Lange,

Joost Raessens, and Imar de Vries 
The publication of this book was made possible by the Utrecht Center for Game Research (one of the focus areas of Utrecht University), the Open Access Fund of Utrecht University, and the research project Persuasive gaming. From theory-based design to validation and back, funded by the Netherlands Organisation for Scientific Research (NWO).

Cover illustration: Photograph of Begging For Change, MEEK (courtesy of Jake Smallman).

Cover design: Coördesign

Lay-out: Crius Group, Hulshout

$\begin{array}{ll}\text { ISBN } & 97894629845^{2} 3 \\ \text { e-ISBN } & 9789048535^{200} \\ \text { DOI } & 10.5117 / 9789462984523 \\ \text { NUR } & 670\end{array}$

\section{(c) $(\mathrm{PY})$}

Creative Commons License CC BY NC ND

(http://creativecommons.org/licenses/by-nc-nd/3.o)

@ All authors / Amsterdam University Press B.V., Amsterdam 2019

Some rights reserved. Without limiting the rights under copyright reserved above, any part of this book may be reproduced, stored in or introduced into a retrieval system, or transmitted, in any form or by any means (electronic, mechanical, photocopying, recording or otherwise). 